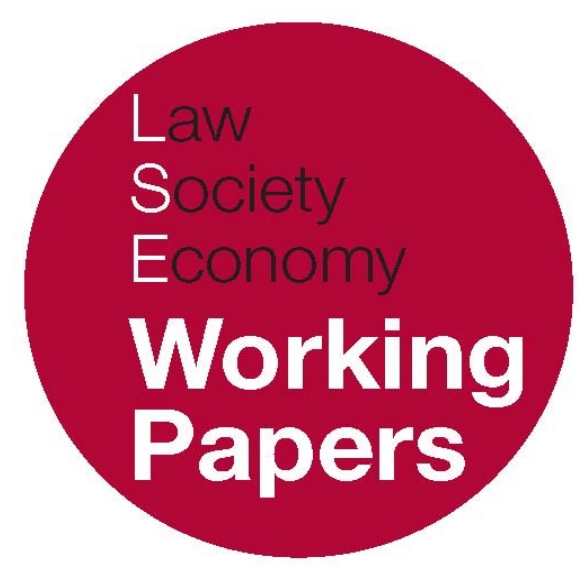

\title{
Gamblers and Gentlefolk: Money, Law and Status in Trollope's England
}

\author{
Nicola Lacey \\ LSE Law, Society and Economy Working Papers 03/2016 \\ London School of Economics and Political Science \\ Law Department
}

This paper can be downloaded without charge from LSE Law, Society and Economy Working Papers at: www.lse.ac.uk/collections/law/wps/wps.htm and the Social Sciences Research Network electronic library at: http://ssrn.com/abstract $=2745378$.

(C) Nicola Lacey. Users may download and/or print one copy to facilitate their private study or for non-commercial research. Users may not engage in further distribution of this material or use it for any profit-making activities or any other form of commercial gain. 


\title{
Gamblers and Gentlefolk: Money, Law and Status in Trollope's England
}

\author{
Nicola Lacey*
}

\begin{abstract}
This paper examines the range of very different conceptions of money and its legal and social significance in the novels of Anthony Trollope, considering what they can tell us about the rapidly changing economic, political and social world of mid Victorian England. It concentrates in particular on Orley Farm (1862) — the novel most directly concerned with law among Trollope's formidable output - and The Way We Live Now (1875) - the novel most directly concerned with the use and abuse of money in the early world of financial capitalism. The paper sets the scene by sketching the main critiques of money in the history of the novel. Drawing on a range of literary examples, it notes that these critiques significantly predate the development of industrial let alone financial capitalism. Probably the deepest source of ambivalence about money in the novel has to do with 'commodification'. As this concern unfolds in Trollope, it tells us a great deal about changing conceptions of property in a world in which industrial capitalism sat alongside practices of speculative investment geared simply to the multiplication of money. Trollope's nostalgia for the world of land sits alongside an increasingly sharp critique of the power of money, and these novels illuminate the rapidly changing economic, political and social world of mid Victorian England. They also speak, as it were, volumes on the relative effectiveness of the different regulatory resources which can be brought to bear upon each form of wealth. And they open some fascinating windows on the gendering of both money and law as concepts in the later Victorian imagination.
\end{abstract}

\footnotetext{
* Departments of Law and Social Policy, Gender Institute, LSE. I would like to thank Anne Phillips for extremely helpful comments on a draft of this paper, and Anna Bilkis-O'Mahoney for her careful editorial work.
} 


\section{INTRODUCTION}

It would be difficult to exaggerate the role of money in the history of the novel. Its importance is of course hardly surprising, given the co-evolution of the novel and capitalism. The institutional arrangements put in place by developing capitalism provided the conditions of existence for the growing production, circulation and consumption of novels; these institutions and the ideas which informed and emerged from them shaped both the form and the substance of the genre. ${ }^{1} \mathrm{~A}$ large critical literature examining the relationship between the novel and money has, accordingly, developed. ${ }^{2}$ This literature is, inevitably, diverse, and in particular takes a number of views on how far economic developments determined the form and content of the novel; and on how far the moral universe of the novel, focused on character, in effect presents an imagined alternative or ideological supplement to the 'real' world of political economy, focused on money. ${ }^{3}$ But many scholars have noted, from their different viewpoints, a growing ambivalence about money in the moral economy of the novel over the course of the eighteenth and, particularly, nineteenth centuries, coinciding with market forces becoming ever more pervasive and intense, and with land gradually being supplanted by money as the primary marker of wealth. This is accompanied by an accumulating perplexity about the norms which should govern pecuniary propriety. It is therefore not surprising that, as John Vernon has noted, money is 'perhaps the most common theme in nineteenth century fiction', ${ }^{4}$ in which that perplexity is symbolised by the shift from the unashamed treatment of financial exchange and power across public and private spheres in books like Defoe's Moll Flanders or Roxana, through Jane Austen's biting irony about the persisting relevance (yet supposed disavowal) of financial calculation in the marriage 'market,' to the critique of the distorting power of financial incentives and the abuse of monetary power in writers like Dickens, Eliot or Trollope.

\footnotetext{
${ }^{1}$ See for example Thomas Keymer and Peter Sabor, Pamela in the Marketplace: Literary Controversy and Print Culture in Eighteenth Century Britain and Ireland (Cambridge University Press 2005); Simon R. Frost, The Business of the Novel (London: Pickering and Chatto 2012).

${ }^{2}$ See, variously, Ian Watt, The Rise of the Novel: Studies in Defoe, Richardson and Fielding (Berkeley: University of California Press, London; Chatto and Windus 1957; Hogarth Press 1987); Michael McKeon, The Origins of the English Novel 1600-1740 (Baltimore: Johns Hopkins University Press 1987); Dermot Coleman, George Eliot and Money: Ethics, Economics and Literature (Cambridge: Cambridge University Press 2014); James Thompson, Models of Value: Eighteenth-Century Political Economy and the Novel (Durham, N.C. and London: Duke University Press 1996); Margot C. Finn, The Character of Credit: Personal Debt in English Culture, 17401914 (Cambridge University Press 2003); Alexander Dick, Romanticism and the Gold Standard: Money, Literature, and Economic Debate in Britain 1790-1830 (London: Palgrave Macmillan 2013); Elise B. Michie, 'Buying Brains: Trollope, Oliphant and Vulgar Victorian Commerce' (2001) 44 Victorian Studies pp.77-97; Douglas G. Baird, 'Law, Commerce and Gender in Trollope's Framley Parsonage, in Martha C. Nussbaum and Alison L. LaCroix, Subversion and Sympathy: Gender, Law and the British Novel (Oxford and New York: Oxford University Press 2013) pp.207-15; John Vernon, Money and Fiction: Literary Realism in the Nineteenth and Early Twentieth Centuries (Ithaca and London: Cornell University Press 1984). Somewhat different, but also relevant to the resonance between novels and the concerns of the social sciences, see also Michael SukYoung Chwe's intriguing Jane Austen: Game Theorist (Princeton and Oxford: Princeton University Press 2013).

3 Thompson, Models of Value op. cit., p. 8

4 Vernon, Money and Fiction op. cit., p.7
} 
The nineteenth century accordingly presents itself as an interesting focus, the steady triumph of money, juxtaposed as it was with a continuing attachment to the status deriving from the landed order, yet a lack of faith in the capacity of the older codes of honour to constrain the power of money. ${ }^{5}$ In the century's wider cultural reception of developing of economic theory, too, there was much debate, and some discomfort, as Adam Smith's conception of political economy as in effect incorporating moral philosophy ${ }^{6}$ gradually gave place to a more technical conception of economic logic in the work of David Ricardo (1772-1823). ${ }^{7}$ While many influential thinkers, notably John Stuart Mill, ${ }^{8}$ aspired to preserve an ethical dimension in economic thinking, the steady professionalization of economics led inexorably towards an increasingly formalised and mathematically driven approach. This was a discomfort which also realised itself in an associated anxiety about the maximising and instrumental form of utilitarian thought. And Mill's own defence of free speech in terms of a 'marketplace of ideas' is symptomatic of how widely market analogies had already spread in mid nineteenth century social thought. But were market mechanisms really sufficient to curb the potentially unruly power of money? And how could the law and other social normative systems be arranged to temper and channel that power? This ambivalence arguably reaches its apogee with the dystopian image of a world divided between a dissipated old order and a corrupt new order of financial capitalism painted by Anthony Trollope in The Way We Live Now (1875) - justly described by economic historian Martin Daunton as presenting 'a particularly jaundiced view of the corrupting power of money' amid the 'scramble for profits' - and, a few years later across the channel, by Emile Zola in his comparable critique of a banking scandal, simply and significantly entitled L'Argent (1891). ${ }^{10}$

In this paper, I will examine the wide range of conceptions of money and its legal and social significance in the novels of Anthony Trollope - a writer whose nostalgia for the world of land sits alongside an increasingly sharp critique of the power of money - considering what his novels can tell us about the rapidly changing economic, political and social world of mid Victorian England. In the first section of the paper, I set out what I take to be the main critiques of money which we might expect to find explored in the history of the novel. Here I note, drawing

\footnotetext{
${ }^{5}$ On Trollope as an example, see ibid., p.114.

${ }^{6}$ The Wealth of Nations (1776)

${ }^{7}$ Coleman George Eliot and Money op. cit., p.16 ff., p.120; Thompson, Models of Value op. cit., p.17.

8 Principles of Political Economy 1848

9 Wealth and Welfare: An Economic History of Britain (Oxford: Oxford University Press 2007) p. 169.

${ }^{10}$ This is not to imply that money was about to decline as a literary preoccupation. Think, for example, of Henry James' fortune hunters, with Gilbert Osmond of The Portrait of a Lady (1881) succeeded by Kate Croy of The Wings of the Dove (1902) (on which see Vernon, Money and Fiction op. cit., pp.172-193) and even the Prince in The Golden Bowl 1904). Indeed, James' fiction evinces a fascination with the power of money and indeed with commodification: Mrs Newsholme and Adam Verver seek, in their more proper ways, to 'buy', respectively, Strether and Charlotte in The Ambassadors (1903) and The Golden Bowl (1904), just as surely as Melmotte purchases people in The Way We Live Now. Yet James introduces a new degree of nuance to the reading of commodification: for example, while Adam Verver's collecting habit betokens monetary power which stands in for a true appreciation of value, modestly placed Maria Gostrey's collecting habit betokens her cultural taste and ability to transcend market logics.
} 
on a range of literary examples, that these critiques significantly predate the development of industrial let alone financial capitalism. And I note, conversely, that the capacity of the codes of honour and gentility deriving from the obligations attendant on older forms of social status to underpin the integrity of commerce, which so often form the object of literary anxiety and nostalgia, remain central preoccupations and symbolic resources as we move into the second half of the nineteenth century, albeit in new guises. I then move to Trollope, concentrating in particular on Orley Farm (1861-2) - the novel most directly concerned with law among his formidable output - and The Way We Live Now (1875) - the novel most directly concerned with the use and abuse of money in the early world of financial capitalism. In these and other novels, I argue, Trollope's work epitomises both the multiple meanings which money has and the many functions which money serves in novels, as well as its fundamental ambivalence. The two novels present some interesting contrasts in terms of their conceptions of money and its significance, with money or wealth deriving from social status gradually displaced by social status deriving from money, or from the reputation of wealth - with interesting implications for the legal, moral and other resources which can be drawn upon to temper the power of money in an increasingly urbanised and fluid world. The books not only tell us much about changing conceptions of property in a world in which the old world of landed gentry and the newer one of industrial capitalism (which features little in Trollope, but large in Dickens and Gaskell, for example) sat alongside practices of speculative investment geared simply to the multiplication of money. They also speak, as it were, volumes on the relative effectiveness of the different regulatory resources, including law, which can be brought to bear upon each form of wealth. And they open some fascinating windows on the gendering of both money and law as concepts in the later Victorian imagination.

\section{THE ALCHEMY OF MONEY: MIRACLE OR MECHANISM OF ALIENATION?}

In Trollope's and Zola's dystopian novels of the late 19th Century, money is a fundamentally ambivalent thing. On the one hand, it is fecund: 'The fields will cease to lie fallow, roads and canals will appear, new cities will rise from the ground and life will at last return... Money will perform these miracles'.11 On the other hand, it is potentially destructive and corrupting: 'filthy', a pollutant, even if, like dung, a fertile one. In this section, I analyse various sources of ambivalence about money, and situate them briefly within the history of the novel.

\footnotetext{
${ }^{11}$ Emile Zola, Money (1891: Oxford World's Classics edition, transl. Valerie Minogue (Oxford: Oxford University Press 2014)) p.65.
} 
Probably the deepest source of ambivalence about money in the novel has to do with what we have come to call 'commodification.' The most vivid, and searching, analysis and critique of the commodifying power of money under capitalism is that of Karl Marx. Here is Marx on, as James Thompson aptly puts it, the 'terrifying... alchemical properties of money':12

That which I am unable to do as a man.... I am able to do by means of money.... Money, then, appears as this overturning power against the individual and against the bonds of society, etc.... It transforms fidelity into infidelity, love into hate, hate into love, virtue into vice, servant into master, master into servant, idiocy into intelligence, intelligence into idiocy. ${ }^{13}$

But it would be a mistake to see this worry about commodification as being distinctively Marxist. For example, Michael Walzer's famous argument that the world should be seen in terms of different Spheres of Justice ${ }^{14}$ such as education, health, politics or personal life, and that power or goods in one sphere should not entitle anyone to greater power or goods in another, is premised on a notion of incommensurable goods which should not be able to be traded in terms of a single currency such as that most obviously represented by money. Of course, parallel economies - economies of esteem, class, integrity, honour, education, wealth are to be found across the centuries in literature. And the dominance of money as a measure of economic value, premised on its ability to transcend those distinctions — itself epitomised in Bourdieu's decision to frame his broad typology of parallel systems of social power in terms of social, human and symbolic 'capital'15 — has long caused perplexity. Particularly in a modernising world of increasing relative individual autonomy, ${ }^{16}$ is the willingness to reason practically in terms of trading off incommensurables a sign of moral corruption or of moral maturity? 17

In framing his later, rather more precise critique of money in Capital, Marx himself quoted not only Shakespeare's famous image of money as 'the common whore of mankind,' that which will 'make black white; foul, fair; wrong, right; base noble, old young; coward valiant.' (Timon of Athens 4.3) but also Christopher Columbus:

12 Thompson Models of V alue op. cit., p.35.

13 The Economic and Philosophical Manuscripts (1844: ed. Dirk J. Struik: New York: International Publishers 1964) pp.167-169, quoted in Thompson op. cit., pp.35-36; cf., Marx, 'Capital is money, capital is commodities. By virtue of it being value, it has acquired the occult ability to add value to itself. It brings forth living offspring, or, at the least, lays golden eggs'. (1867) Capital Vol. I, Ch. 4, pp.171-172.

14 Spheres of Justice: A Defense of Pluralism and Equality (New York: Basic Books 1983)

15 See for example Pierre Bourdieu, 'The Forms of Capital (1986)

16 That relativity itself, of course, increasingly premised on money. https://www.marxists.org/reference/subject/philosophy/works/fr/bourdieu-forms-capital.htm

17 As in effect argued by Michael Suk-Young Chwe, Jane Austen: Game Theorist op. cit., pp.228-229: for Chwe, Austen's irony betokens a mature recognition that strategic reasoning inevitably means trading off one good against another, even if this does not imply that we should be able to 'buy' goods in one 'sphere of justice' with goods in another. 
'Gold is a wonderful thing! Its owner is master of all he desires. Gold can even enable souls to enter Paradise' (Columbus, in his letter from Jamaica, 1503). Since money does not reveal what has been transformed into it, everything commodity or not, is convertible into money. Everything becomes saleable and purchaseable. Circulation becomes the great social retort into which everything is thrown, to come out again as the money crystal. Nothing is immune from this alchemy, the bones of saints cannot withstand it... [1] t extinguishes all distinctions. But money is itself a commodity, an external object capable of becoming the private property of any individual. Thus the social power becomes the private power of private persons..$^{18}$

Already in these brief quotations, we can begin to distinguish various different strands of critique or anxiety, of which several seem particularly important. The first is the potential for abuse of power which comes with the individual capacity to accumulate a source of influence which travels readily across the 'spheres of justice'. The second is the capacity of money, or the desire for money, and the power which money brings, to corrupt or distort human motivations, to alienate and to encourage greed, avarice, overweeningness. Two further, related implications for human motivation are important here. One is the power of money - understood as treasure as distinct from a medium of exchange — to produce a kind of fetishism symbolised by literary figures from King Midas in ancient Greek mythology to Silas Marner (1861). ${ }^{19}$ Another is the capacity of the profit motive to engender a pure form of instrumentalism focused on short term gain rather than the longer term investment needed to foster stability and the production of more complex goods a risk of which such a deep thinker as George Eliot was keenly aware, in not only her writing but her personal investment strategies. ${ }^{20}$

A fifth source of concern, particularly though not exclusively attaching to 'virtual' forms of money which rely on trust and reputation - credit in the old fashioned sense - is the potential for money to become a means or object of dishonesty or fraud. As forms of paper credit proliferated, underpinning the ease and expansion of trade, the chances for fraud expanded; and anxiety about the reliability of money increased in parallel with its detachment from objects of ostensibly 'real' value. ${ }^{21}$ Of course, the invention of these forms of paper money significantly predate the nineteenth century. Already in 1720,22 Defoe was noting

\footnotetext{
${ }^{18}$ Capital I, p.163, Quoted in Thompson Models of Value op. cit., p.36; cf., Marx's reference to money as 'the galvano-chemical property of society,'Vernon, Money and Fiction op. cit., p.9

19 As Vernon has observed (Money and Fiction op. cit., pp.35-36), it is significant that misers in nineteenth century fiction tend to be old, symbolising an attachment to a disappearing world in which money took the form of the 'really' valuable substance of gold or other treasure.

${ }^{20}$ See Coleman, George Eliot and Money op. cit., pp.148-149. Eliot's Brother Jacob (1864) provides a particularly dystopian view of a purely instrumental, profit-driven world; as, in a different, industrial context, does Charles Dickens' Hard Times (1854).

21 Alexander Dick, Romanticism and the Gold Standard op. cit.

22 The Chimera: Or, the French Way of Paying National Debts, Laid Open (1720).
} 
the quality of paper money as 'meer Air and Shadow, realizing Fancies and Imaginations, Visions and Apparitions'23 — indeed about as different from the cumbersome gold coins which his fictional character Colonel Jack struggles to carry or hide as it was possible to be. But the widespread acceptance of paper money and of other forms of credit - indeed their normalisation - made these issues of trust much more acute in the nineteenth century. Indeed, Trollope has one of his most unsympathetic creations, Sir Felix Carbury of The Way We Live Now, put his finger deftly on this issue, when his mother Lady Carbury presses him to elope with Marie Melmotte in the hope of extracting a promise of a regular income from her father. As Sir Felix drily points out to his mother - voicing the 'virtual money' analogue to the problem encountered by Colonel Jack — you can't very well put $£ 10,000$ a year in your pocket....24 And this in turn can lead to a (sixth) anxiety about the capacity of moral, political, legal or other norms and regulatory systems to control the various forms of abuse to which money - in a commercial world beyond the reach of older normative systems of neo-feudal propriety — can give rise. Were the new regulatory currencies, in short, worth the paper they were written on?

Seventh, there is a moral, even metaphysical, worry about the capacity of money's success as a medium of exchange to muddy the intrinsic importance of distinctive values amid the relentless sway of market forces: the case for certain moral limits on markets expressed, for example, in Michael Sandel's recent What Money Can't Buy. ${ }^{25}$ And finally, eighth, there is an anxiety, particularly vivid in Dickens and Gaskell, but present to some extent in most of the mid nineteenth century realist authors, of the corrosive effects of want of money, and of poverty, particularly in the cities, which were rapidly growing but still inadequately regulated and hugely vulnerable to volatility in the business cycle. The legal restructuring of debt recovery in the middle decades of the nineteenth century, and the significant extension of the law of bankruptcy to non-traders in 1861, reduced imprisonment for debt for those with sufficient social and economic capital to take advantage of this new legal regime - thereby removing one of the most common tropes of the modern novel. But the creation of county courts, with their inexpensive enforcement proceedings and capacity to imprison for debts of less than $£, 50$, in effect made working class debtors yet more vulnerable to imprisonment and introduced a longstanding class distinction into the legal regime for debt recovery. ${ }^{26}$

\footnotetext{
23 Quoted in Vernon, Money and Fiction 40; on Colonel Jack (1722), see pp.13-15: Colonel Jack ultimately solves his difficulty by buying a pair of trousers with concealed pockets.

${ }^{24}$ The Way We Live Now Chapter 23 [98-99]

25 What Money Can't Buy: The Moral Limits of Markets (Macmillan 2012). Note that Sandel's argument resonates with Walzer, but that they are not co-extensive: Sandel argues for limits on markets even where their use would not necessarily lead to trading across the spheres of justice other than in the definitional sense of opening any good to market exchange. Cf., Anne Phillips, Our Bodies, Whose Property? (Princeton: Princeton University Press 2013); Bev Skeggs, 'Values beyond Value? Is anything beyond the logic of capital?' (2014) 65 British Journal of Sociology pp.1-20.

26 See Daunton, Wealth and Welfare op. cit., pp.433-434. This is of course not to say that want of money and fear of debt disappeared as concerns of the more advantaged — especially of women, whose ability to earn money was far more constrained by social norms than was that of men.
} 
It is, of course, both tempting, and reasonable, to associate the urgency of all these anxieties and criticisms with the completeness and intensity with which capitalism had developed. The reach of market principles increased in England, for example, through the eighteenth, nineteenth and indeed twentieth centuries, albeit in fits and starts prompted by factors as diverse as the political complexion of government, the shape of regulatory systems, the influence of laissez faire ideas in political economy, the development of monetary, credit and banking technologies, and of course the economic and geopolitical environment. But it is worth reminding ourselves that some such anxiety about commodification and its attendant ills is a very constant theme in literary culture - as indeed is an awareness of the potential of commodification to advance social exchange, social progress - and indeed individual ambition. In Shakespeare's Richard II Bagot comments on the capacity for financial incentives to shape political preferences and even loyalty:

And that's the wavering commons: for their love

Lies in their purses, and whoso empties them

By so much fills their hearts with deadly hate.

(Richard II Act II Scene ii)

And in Henry IV part II Falstaff, with characteristic opportunism, notes that there appear to be no limits to what can be turned into a means of exchange:

A good wit will make use of anything;

I will turn diseases to commodity.

(Henry IV Part II Act 1 scene ii)

Indeed, for Shakespeare, even reputation can be represented as a commodity, capable of being stolen:

Who steals my purse steals trash; 'tis something, nothing;'

Twas mine, 'tis his, and hath been slave to thousands;'

But he that filches from me my good name

Robs me of that which not enriches him

But makes me poor indeed.

(Othello Act 3 scene iii)

But, undoubtedly, literary preoccupations with the power of money accelerate with the growth of a mercantile economy and with the urbanisation which diluted the local knowledge and status-based means of reading character which stabilised social judgments of honesty and credit in the early modern era. ${ }^{27}$ For example, in Sarah Fielding's delightful The Adventures of David Simple Containing an Account of his Travels

27 See Finn, The Character of Credit op. cit. 
through the Cities of London and Westminster in Search of a Real Friend (1741),28 the eponymous hero becomes disillusioned after he discovers that his adored brother has falsified their father's will to get the whole estate. David manages to recover the estate and, providing basic support for his brother, decides to set out on travels in search of a real friend. Reasoning that he would be better off in London, where everything happens anyway(!), he lodges with a series of characters, and witnesses various kinds of corruption, vanity, stupidity, cruelty, thoughtlessness across the social classes. The disingenuous David, constantly shocked by people's inhumanity to one another, ponders the central ethical and practical problem of an unequal, commercial society: the less well off must pander to the ridiculous wants of the rich for their survival, and must moreover work out how to manage inevitable financial obligations to strangers amid confusion about how to recognise character in the fluid world of London. Much in the style of those taken in by Trollope's monstrous Melmotte over a century later, David struggles with the treachery of appearances in relation to both character and conduct, and the frequent gap between merit and reputation. Yet Fielding's critical analysis of the perils of mercantile London - and a critique of conspicuous consumption of which latter day socialist feminists would have been proud, - is combined with a ringing endorsement of the benefits of consumption for economic prosperity and distribution:

She said, she was considering, amongst the variety of Shops she saw, how very few of them dealt in Things which were really necessary to preserve Life or Health; and yet that those things which appeared most useless, contributed to the general Welfare: for whilst there was such a thing as Property in the world, unless it could be equally distributed, those People who had little or no share of it, must find out Methods of getting what they want, from those whose Lot it is to have more than is necessary for them; and, except all the World was so generous, as to be willing to part with what they think they have a right to, only for the pleasure of helping others; the way to obtain any thing from them is to apply to their Passions: As, for instance, when a woman of Fashion goes home with her Coach loaded with Jewels and Trinkets, which, from Custom, she is brought to think the cannot do without, and is indulging her Vanity with the Thoughts of out-shining some other Lady at the next Ball — the Tradesman who receives her Money in Exchange for those things which appear so trifling, to that Vanity perhaps owes his own and his Family's Support.'29

This preoccupation with 'the way we live now' as society modernises, urbanises, commercialises goes back to the very origins of literary realism in England. Indeed, as Juliet Mitchell persuasively argued in her essay on Daniel Defoe's Moll Flanders

\footnotetext{
${ }^{28}$ Sarah Fielding, The Adventures of David Simple Containing an Account of his Travels through the Cities of London and Westminster in Search of a Real Friend (first published 1741: Kessinger Rare Reprints 2007).

${ }^{29}$ Ibid., p.143
} 
(1722),30 this very early novel sets the scene for what is to follow. For it is about the establishment of a capitalist society, and about the confusions and tensions which are emerging in a world in which money is becoming queen, and yet clear norms of right and wrong in relation to money - the fluid line between enterprise and dishonesty — have yet to be firmly asserted. As Mitchell puts it, the oppositions between wife and whore, thief and capitalist, 'the clear-cut oppositions of crime good citizenship, morality and immorality... have not yet separated themselves out'. ${ }^{31}$ Note that, once again, a leap to Trollope's vision of late nineteenth century England produces strikingly similar examples, like Lady Monogram, who 'had but a confused idea of any difference between commerce and fraud'. ${ }^{32}$ In Defoe's context, incest and murder become the true emblems of wrong, and though Moll is held up as finding moral development and repentance, the values which animate her enterprise, cunning, activity, work, resourcefulness - underpin her thievery and prostitution just as they do her ultimate marriage and success as a business woman. Hence she is a heroine even as she is a thief and prostitute, emblemising the capitalist figure, a new 'universal' type born from the chaos of revolutionary change. ${ }^{33}$ The confusions which we see played out in Moll Flanders are, in short, an early example of the moral and legal conflicts engendered by capitalism, which would shape the pages of the novel for centuries to come:

It is not the righteous ending that prevents Moll Flanders from being a pornographic tale of wickedness but rather the fact that Moll is good even while a thief and a prostitute and just as bad or just as good even while she is a wife and investor. It is a question of the similarity of the crimes and the laws against them, of 'acceptable society' and its 'underside'. 34

\footnotetext{
${ }^{30}$ Juliet Mitchell, 'Moll Flanders, The Rise of Capitalist Woman’ pp.195-218 of Women: The Longest Revolution (London: Virago 1984); reprinted from her introduction to the Penguin edition of Moll Flanders (Harmondsworth 1978).

${ }^{31}$ Ibid., p. 202; see also pp.209-211

32 Penguin Classics, 1994, with an introduction by Frank Kermode, p.467

${ }^{33}$ Mitchell pp.217-218; note that this 'universal type', at least in its feminine persona, was about to disappear for well over a century: Nicola Lacey, Women, Crime and Character (Oxford: Oxford University Press 2008) 34 Mitchell, 'Moll Flanders, The Rise of Capitalist Woman' op. cit.: Cf., Daniel Defoe, Roxana: The fortunate Mistress fp 1724, (Oxford World's Classics ed. John Mullan, Oxford: Oxford University Press 1996). Similar to Moll Flanders, but in some ways a more egregious tale because though Roxana originally turns to vice because of poverty, she persists with it when rich, and is primarily motivated by greed and a desire for status and wealth. In particular, there is a fascinating scene in Amsterdam when Roxana argues with the Dutchman, who wants to marry her. She suspects her first husband is still alive, and yet more strongly she does not want to give up her wealth to a man. Confronted with the Dutchman's spirited defence of a woman's privileges in the prevailing sexual division of labour, Roxana returns, with yet greater spirit, 'that while a woman was single, she was a masculine in her politick Capacity; that she had then the full Command of what she had, and the full Direction of what she did; that she was a man in her separated Capacity, to all Intents and Purposes that a Man could be so to himself....' but if she marries (149) 'all is the Interest, Aim, and View of the Husband; she is to be the passive Creature you spoile of, Said I...' And so it goes on, with him arguing for men's honour to women, and Roxana objecting that she doesn't want to be subject to that kind of discretionary power. Very fascinating - a feminist argument shaped out of a moral/pragmatic dilemma! Cf., also her discussion with her financial adviser Sir Robert (171); 'I knew no State of Matrimony but what was, at best, a State of Inferiority, if not of Bondage; that I had no Notion of it that I liv'd a Life
} 
While a real change is betokened by the fact neither Thackeray's rather similar character Becky Sharp of V anity Fair a century later, let alone Trollope's Melmotte, could possibly qualify for the description 'good,' the very same tensions animate the worlds of all three novels.

Following Defoe's defining contributions to the genre, the realist novel's contribution to the social analysis of money, its meanings and effects, particularly on human motivation, continued unabated, just as the novel itself became a key object of market activity and a stimulant of both consumption and production. Samuel Richardson's Pamela (1740) - as befitted the creation of such an effective literary entrepreneur - showed herself to be an astute strategist, experiencing little difficulty in weighing up the likely contributions of virtue, reputation and skill in her 'value' to Mr. B. (She also - albeit unwittingly - stimulated a veritable industry of Pamela cultural and material paraphernalia which arguably left the sophisticated business strategies of nineteenth century authors and publishers, as they adapted the form of the novel to match the opportunities and constraints offered by changing market circumstances and print and distribution technologies, in the shade.) ${ }^{35}$ Even Pamela's saintly and much put upon successor, Clarissa (1747-8), features an interesting sub-theme about the influence of money, amid the upwardly mobile classes and the urban dweller: like the prostitutes ruined and then deployed by Lovelace, Clarissa's own family - moneyed but not really genteel - is motivated, and corrupted, by greed. Conversely, the aristocracy, epitomised by Lord M and, in a lesser sense, Lovelace, are castigated for their decadence or, at best, moral feebleness - a theme which, once again, could be taken straight from the pages of Trollope's dystopia well over a century later. Another recurrent theme is that of the corrupting power of the city: for example, in Henry Fielding's Joseph Andrews (1742) London - as well as an excess of money - are seen as sources of evil. Even in respect of pre-capitalist institutions, an analysis based on incentives and exchange across spheres of justice is pervasive in realist novels. For example, Fielding reminds us of the financial incentives people had to report crimes - reward money - and the incentives to perjury that this created: accompanying these scenes are images of lazy, complacent justices with little incentive to look carefully into the cases brought before them.

Yet novelists did not always, or unambiguously, bite the hand that fed them. Even Henry Mackenzie's The Man of Feeling (1771), though deploring the ascendancy of wealth over birth (and the use of jail for debt), exhibits some ambiguity on whether the hero is to be admired or derided: is he a credulous fool who is getting pleasure through his exquisite sensibility, or a virtuous if unworldly person unsuited

of absolute Liberty now; was free as I was born, and having a plentiful Fortune, I did not understand what Coherence the Words Honour and Obey had with the Liberty of a Free woman.... And seeing Liberty seem'd to be the Men's Property, I wo'd be a Man-woman; for as I was born free, I wo'd die so'.

${ }^{35}$ See Keymer and Sabor, Pamela in the Marketplace op. cit.; Coleman, George Eliot and Money op. cit.; Frost, the Business of the Novel op. cit. 
to the realities of the commercial age?36 And 70 years later, while Elizabeth Gaskell's North and South (1855), in its extended meditation on industrial capitalism, deplores the tendency to chase short term profit rather than longer term goals, let alone a more complex conception of the good life, it nonetheless has the successful industrialist John Thornton persuasively assert the power of reputation effects to instil a long term perspective. And although the heroine, Margaret, observes that trade/ the profit motive invites deceit; and worries about the 'deep selfishness of competition', ${ }^{37}$ she recalls the harshness of the agricultural labour she knew in the South of England, and ultimately sympathises with Thornton's aspiration to transcend the pathologies of capitalism by knowing his workers and cooperating with them, building a relationship 'beyond the cash nexus' even while recognising that conflicts of interest will persist.

As the realist novel develops in both scale and ambition during the nineteenth century, the role which money plays retains its centrality while acquiring yet greater significance as a key to character and to the quality of a social order. In Thackeray's Vanity Fair (1848), the significantly named Becky Sharp is a mirror in which we can see the hypocrisy of Regency society, in which status, character and reputation are ostensibly held dear, yet money and power are what count. And how people handle money, and their own desire for it and need of it, becomes ever more central to our reading of them. For example, George Eliot's idealistic - but ambitious - doctor, Lydgate of Middlemarch (1871-2), is ultimately tainted by his inability to curb his domestic consumption and his consequent unwitting financial dependence on a discredited man: money can travel as a medium of infection as well as of exchange. As he puts it,

It is still possible that Bulstrode was innocent of any criminal intention - even possible that he had nothing to do with the disobedience, and merely abstained from mentioning it. But all that has nothing to do with the public belief. It is one of those cases on which a man is condemned on the ground of his character - it is believed he has committed a crime in some undefined way, because he had the motive for doing it; and Bulstrode's character has enveloped

\footnotetext{
${ }^{36}$ The examples could be multiplied: as Margaret Doody argues in her introduction to Charlotte Lennox, The Female Quixote: or, The Adventure of Arabella fp 1752; (Oxford World's Classics edited by Margaret Dalziel, with an introduction by Margaret Anne Doody 1989), the very birth of Augustan realism might be seen as mirroring the interest of the emerging bourgeoisie, the social power of money and status, and of a Whig governmental power base keen to suppress the romance of Jacobitism. Nor is this period literature short of images of the nexus between wealth and legal security: "Wealth and despotism easily know how to engage those laws as the coadjutors of their oppression, which were perhaps at first intended... for safeguards for the poor...': how shall anyone poor have access to 'the tedious dear-bought remedy of the law?' William Godwin, Things as They Are, or, The Adventures of Caleb Williams 1794: (Penguin Classics edition 1988) p.75, 188.

${ }^{37}$ Elizabeth Gaskell, North and South (1855: Penguin Classics edition 1996) Chapter 50.
} 
me, because I took his money. I am simply blighted - like damaged ear of corn... ${ }^{38}$

And yet Eliot is clear sighted about the both the necessity and the advantages of money: one of her most sympathetically flawed characters, Mr. Farebrother, notes with some irony how many of our good deeds depend on money: 'It's rather a strong check to one's self-complacency to find out how much of one's right doing depends on not being in want of money'. ${ }^{39}$

\section{THE USES - AND ABUSES - OF MONEY IN TROLLOPE'S NOVELS}

The desire of accumulating property, combined with the industry necessary for doing so, is perhaps of all qualifications for civilisation the most essential. ${ }^{40}$

As this quotation illustrates, Trollope was very far from being a general critic of either individual accumulation of property or the desire to acquire it. Indeed, as he shows to comic effect in Orley Farm, ${ }^{41}$ the commercial world has systems of norms and rules of etiquette every bit as elaborate as the aristocracy. He was moreover quite explicit about the importance of not only property in general but money in particular:

[T] $\mathrm{t}$ is a mistake to suppose that a man is a better man because he despises money. Few do so, and those few in doing so suffer a defect. ${ }^{42}$

He moreover regarded his own books as a 'marketable commodity', and was proud of the professionalism with which he produced them. ${ }^{43} \mathrm{He}$ did, however, see particular risks about money; and he was, of course, writing in a world in which money had gradually emerged as a source of social capital in its own right, independent of land. ${ }^{44}$ It is therefore hardly surprising that money features large in his works - and that his treatment of money offers fascinating insights into the ambivalence with which its alchemical powers were viewed in the late nineteenth century. But the treatment of money is also put to broader symbolic purpose, most notably in terms of the integrity or otherwise of personal motivations and of

38 George Eliot, Middlemarch (1871-2: Penguin Classics, based on the second edition of 1874, 1994) Chapter 76 p. 821

${ }^{39}$ Middlemarch p.673; also quoted in Frost, The Business of the Novel op. cit., p.107

40 Anthony Trollope, quoted in Victoria Glendinning, Trollope (London: Pimlico 1992) p.418

41 Op. cit., Chapter 6 Book 1: 'The Commercial Room.'

42 Anthony Trollope, An Autobiography p.106

${ }^{43}$ See Vernon, Money and Fiction op. cit., p.153, quoting Trollope's An Autobiograpby op. cit., p.109

${ }^{44}$ See Guyora Binder and Robert Weisberg Literary Criticisms of Law (Princeton: Princeton University Press 2000) pp.219-220 
financial dealings, which act throughout his novels as a sign of the state of the nation: of 'how we live now'.

Money, of course, can represent several different things. Most obviously, it can represent treasure or wealth; a unit of value; a medium of exchange; and a means of payment. Each of these qualities or meanings of money features in Trollope's work, but they are in addition put to use for a wide variety of literary purposes. It is worth identifying several of the most important of these. First and foremost, the relationship of any given character to money - their attitude to it, how they go about getting it, and how they use it — is a key test of character, and hence quite central to the purpose of the novel. A good example here would be the contrast drawn in The Way We Live Now between Sir Felix Carbury and his cousin Roger Carbury. Sir Felix sees money as an end in itself and as a means of idle selfgratification; and he regards people like Melmotte, Melmotte's daughter Marie, and even his own mother, as mere means to that overarching end. Roger, by contrast, has a balanced and mature attitude to money: no man, he claims, becomes a gentleman by reason of his wealth; a decent man husbands his estate - in the original sense of 'economy' - wisely, recognising its true value. Roger also observes a dense set of norms about credit and debt, for example never assuming a debt he is unable to discharge, and never keeping his tradespeople waiting for payment. In another example, Trollope signals that John Crumb, who on first introduction seems a rather feeble character, should not be underestimated, when he tells us that 'He could earn money, and having earned it, could spend and keep it in fair proportion'.45 A similar contrast is drawn in Orley Farm, with the extended debates about the potential marriage of Felix Graham and Madeline Staveley serving to underline the maturity of Judge Staveley's character: he understands not only the value but the limits of money, and mediates between Felix's lack of realism and Lady Staveley's temptation to elide money, social status and even personal worth. ${ }^{46}$ In counterpoint, Lady Mason has been brought up to regard 'wealth and riches as all'47 - a background which is represented as underpinning the fundamental moral misjudgement on which the book turns.

Second, money is a driver of plot. Evidently, an undisciplined and unscrupulous pecuniary acquisitiveness, along with the legal and economic arrangements which facilitate it, is not only a primary focus of the novel's depiction of 'the way we live now', but also a driver of much of the action which makes up the story. Indeed, as James Thompson has suggested, capitalist exchange might be seen more generally as a metaphor for change and transformation in the realist novel. ${ }^{48}$ Moreover the need for money is a fundamental motivating force, for good or ill, across Trollope's work and beyond it: need, not merely in terms of basic wants

45 The Way We Live Now op. cit., Chapter XXXIII [142]

46 Orley Farm op. cit., Book 2 pp.175-184; 248; 349-352.

47 Ibid., book 1: 205.

48 Thompson, Models of V alue op. cit., p.9. 
such as food and shelter, but also, increasingly, in terms of social standing - as is evident in The $W$ ay $W$ L Live Now. 49

Third, money - and/or the reputation for wealth — is a source of personal capacity, power, influence and status. It is something which can be used for ill, as it is by Melmotte, or for good, as it is by Roger Carbury. (In the Barsetshire novels, Trollope presents us, in Miss Dunstable/Mrs Thorne, with a rarer example of someone whose wealth gained commercially — through joint stock banking — is used for good. $)^{50}$ And this sense of money as a source of power connects closely with its dual meaning as a generative force - that which creates the real railway across the US - and as a destructive one - that which creates the desires which give birth to the fantasy of a railway which underpins the company which Fisker, Montague and Montague have set up, and the bubble which Melmotte inflates. Similarly, money has different possible social and psychological meanings: it can be a source of shame or of pride. Roger Carbury takes pride in his family inheritance; and Paul Montague would like to feel pride in money legitimately earned so as to gain the independence which would make it legitimate for him to ask Henrietta Carbury to marry him. But in fact he feels his temporary wealth in the early part of the novel to be a source of shame or guilt ${ }^{51}$ — something on a moral par with the fruits of gambling. Indeed the analogy between gambling and financial speculation is a constant theme in the novel, and attitudes to gambling once again mark out the lines of character: Felix and his friends gamble at the gaming table; Felix plans to gamble on Melmotte not cutting off his daughter; Marie gambles on Felix's promise; Mrs Hurtle gambles on Paul Montague's weakness; Melmotte gambles on almost everything. ${ }^{52}$ The unedifying dance of luckless Marie Melmotte's many suitors is suggestive of the moral corruption of a world in which the pursuit of money has become an end in itself: this is not quite the image of miserly or fetishistic cupidity directed to money as a form of treasure, but nonetheless not far distant from that. ${ }^{53}$ There is also a theme about the moral poverty of a utilitarian, a maximising or an instrumental ethic: everything is about money and commerce in this new world

\footnotetext{
${ }^{49}$ Cf. Vernon's comment on Henry James' grasp of the fact that 'money is the open secret of the life of leisure': Money and Fiction op. cit., p.173.

50 See Michie, 'Buying Brains' op. cit., pp.84-86. As Michie notes, Trollope's attitude to commerce is however somewhat more benign in the Palliser novels (1864-1880).

51 The Way We Live Now op. cit., Chapter 26 [112]

${ }^{52}$ Trollope here builds on a pervasive theme in the novel. To take another salient mid nineteenth century example, it is a mark of Gwendolen Harleth's moral immaturity that the book opens with her at the gaming table - and a mark of the distance of her moral travel when she consults Daniel Deronda, hero of George Eliot's eponymous novel (1876), towards the end of the book, about whether she should give up the wealth which she acquired on Grandcourt's death, as a result of her earlier gamble in marrying him. In another example of the way in which money is used by authors to indicate character, Deronda advises her to keep the money and to use it for good purposes: in these circumstances, the moral quality of the money depends entirely on the use to which it is put. See further Coleman, George Eliot and Money, pp.115-117. The metaphor of gambling - and the exploration of its psychology and social significance — is most fully realised in Fyodor Dostoevsky's The Gambler (1866): see Vernon, Money and Fiction op. cit., pp.117-132 for discussion.

53 As perhaps suggested by the striking phrase, in Marie Melmotte's mouth, that her maid Didon is 'very fond of money': The Way We Live Now op. cit., Chapter 25 [106]
} 
(corruption spreading, like Mrs Hurtle, from America...) $)^{54}$ in which everything, including people, is open to commodification: Melmotte 'buys' aristocrats like Lord Alfred and Miles Grendall; Marie is 'trafficked for,' the 'prey' of both Felix and her father, as they contemplate trading his money for Felix's social status. 55

A further theme lies closer to the question of the legal and other regimes of social regulation surrounding the role of money in the second half of the nineteenth century. This theme has to do with the unreliability of money as a source of value: not merely in the sense of money not being a value in itself, but rather in terms of the way in which certain forms of monetary arrangement lend themselves to abuse or to other calamities attendant on mistakes, accidents or miscomprehensions of one kind or another. This theme runs through Trollope's work, from the complexity of the proprietary arrangements around the alms houses which lead The $W$ arden (1855), the disingenuous Mr. Harding, into trouble; through the stolen cheque which causes such heartache to the Reverend Josiah Crawley in The Last Chronicle of Barset (1867), and the bills of exchange which lead Mark Robarts into error in Framley Parsonage (1861). In this meditation on the dangers of paper credits, Trollope tells the story of Mark Robarts, vicar of Framley, under the patronage of Lady Lufton. Brought up with her son, Lord Lufton, and married to the loyal Fanny, Mark is over-confident and ambitious, and despite his very well paid parsonage, wants to get among the aristocracy, among them the dangerous Nathaniel Sowerby. He signs notes of credit for Sowerby, who basically cheats him, leaving him with a huge debt when Sowerby's ambition to save his estate by marrying wealthy Miss Dunstable (Dr. Thorne 1858) comes to nothing. In the end, when the bailiffs arrive, he has to be rescued by Lord Lufton. ${ }^{56}$

Douglas Baird has argued persuasively that Mark's story represents a morality tale in which his straying beyond home and hearth is symbolised by the bill of exchange, the settlement of which represents a return to domestic and social order. ${ }^{57}$ But it is also a key to this plot that bills of exchange are inherently vulnerable to the honesty of those involved, and a ready source of disaster to the naïve. While Josiah Crawley is, ultimately (and reluctantly), able to resort to the law to establish his innocence in relation to the stolen cheque which he unwittingly tries to use, even this legal resort is highly dependent for its effectiveness on the impeccable reputation and high standing of the key witness: while for Robarts, the law provides no remedy for his own gullibility. Yet more fundamentally, The Way We Live Now

\footnotetext{
54 See for example ibid., p.231, 410

55 Ibid., Chapter 24, and Chapter 11. Indeed, Trollope argued that this sort of money for status marital trade in heiresses 'has become an institution, like primogeniture, and is almost as serviceable for maintaining the proper order of things. Rank squanders money; trade makes it; - and then trade purchases rank by regilding its splendour': The Way We Live Now, quoted in Vernon, Money and Fiction op. cit., pp.44-45.

56 Framley Parsonage (1861) Penguin Classics 2004 with intro by David Skilton and Peter Miles, who meanwhile has fallen in love with Lucy, Mark's sister, to his mother's distress.

57 Baird, 'Law, Commerce and Gender in Trollope's Framley Parsonage' op. cit.; Cf. Vernon's claim (Money and Fiction op. cit., p.113) that debt functions in Trollope as a threat to a safe, closed social world — letting in, inter alia, outsiders such as the Jewish moneylenders and lawyers, Trollope's attitude to whom often presents a painful counterpart to his generally humane approach.
} 
represents a plurality of monetary forms whose value is dubious and subject to manipulation: the signed chits which eventuate from Felix and his Beargarden friends' gambling bouts are worth whatever bargaining power each of the young men has against the other, while, on a more sinister note, Melmotte is described as pondering 'setting the price of money and funds'. ${ }^{58}$

\section{THe Codes of Gentlefolk IN A World of GAMblers? Professionalising THE REgULATION OF MONEY IN TROLLOPE's WORLD}

These examples touch on a further significant monetary theme in Trollope: that regarding the interaction of 'old' and 'new' symbolic and institutional resources or sources of 'credit' in managing the regulation of money and its use. While, certainly, Trollope holds up the 'old' values of Roger Carbury and his world to our admiration, and the new amoral instrumentality of Melmotte's world to our disapproval, he is far from mapping all positive and negative qualities onto the old and new worlds respectively. Even Carbury's land is becoming 'a costly luxury'59 — and we might read his rigidity and difficulty in accepting his younger friend Paul Montague's success in love with Henrietta Carbury as an outdated form of noblesse oblige. The financier Melmotte's reputation for wealth and financial sagacity allows him to hoodwink the dozy lawyers Slow and Bideawhile, being allowed to complete the 'purchase' of a property from the upper class Longstaffes without any money changing hands. (It must be admitted that Melmotte helps things on by forging a letter...). But it is precisely the feckless members of those upper classes Longstaffe among them - who have shored up Melmotte's reputation by lending him - indeed selling him - their names and, along with them, a veneer of gentility. Melmotte has bought them, just as he proposes to sell his daughter. Conversely, $\mathrm{Mr}$ Chaffanbrass' successful demolition of Mr. Dockwrath by cross-examination in Orley Farm is accomplished by means of an assault on his character, by showing the latter's interest in the case. Bereft of further sources of credit/symbolic capital, Dockwrath is powerless - unlike Lady Mason, and in the teeth of the facts - to rebut the imputation of dishonesty.

All this, I would suggest, betokens an anxiety about the regulatory systems available to guarantee the security and integrity of monetary — indeed of social transactions in the increasingly anonymous, urbanised and market-driven world of the latter nineteenth century. This was a world in which the (itself illusory) solidity of the gold standard's symbolic enactment of a link between monetary value and 'real' worth was fading from view, and in which paper or even simply confidencebased credit was of supreme importance. And it is worth reminding ourselves that the writing of Trollope's great novel was preceded by a real history of business fraud, speculative bubbles, bank crashes and attempts to regulate money - banking reform, companies legislation, the growth of accounting — which underpins its

58 The Way We Live Now op. cit., Chapter 24 [100]

59 See Vernon Money and Fiction op. cit., p.43 
plot. In particular, the 'Railways mania' of the 1840 s, which led to a financial crisis in 1847, bears some resemblance to the events which unfold in the novel, while the abuses rife in the Board of the South Central Pacific and Mexican Railway resonate with the modes of deception common on Boards which were exposed by the Gladstone Committee in 1836. ${ }^{60}$ The third quarter of the nineteenth century was one of relative prosperity: the extremes of volatility represented by the decadely cycles of boom and bust which had characterised the earlier part of the century had evened out, and the depression which was to dominate the decade following publication of The Way We Live Now had yet to eventuate. But a measure of economic instability characterised even this relatively prosperous period.

The nineteenth century lives up to its reputation as the era of reform in the commercial and banking as in other sectors. But the evolution of regulation lacked consistency of either purpose or execution: indeed, its history reads like an object lesson in the socio-legal insights about the distinction between the letter of the law and its enforcement, and about the unintended consequences of regulatory regimes. The middle of the century saw the consolidation of the centralised power of the Bank of England, including the exclusive right to issue bank notes, in the Bank Charter Act 1844, as well as the creation of the joint stock company in the Joint Stock Companies Act of the same year, with the implementation of accounting regulations in legislation the next year. This was followed in 1855 by the establishment of limited liability in the Limited Liability Act, and in 1856 by a further Joint Stock Companies Act laying down a structure for corporate activity which, as consolidated in the 1986 Companies Act, more or less persists in England today. But at the same time this legislation relaxed accounting regulations, in what was becoming a pattern of movements back and forth between regulatory tightening, followed by worries about its chilling effect, succeeded by relaxation, engendering further abuses or even crises, leading to a re-enactment of the same cycle over again. ${ }^{61}$ Amid the various regulatory reactions and counter-reactions shaped by a still volatile market economy (the 1844 Act was suspended by Parliament in successive crises in 1847, 1857 and 1866,62 and further regulation of accounting standards was introduced in 1866 and 1878 following banking collapses), it is sometimes hard to work out the balance which legislation was trying to achieve as between the impulse to reform, regulate, standardise and stabilise; and the impulse to facilitate the markets on which growth and prosperity were seen to depend. Amid this confusion - or perhaps it would be fairer to say, plurality — of purpose, it is probably not surprising that neither Trollope's nor other novels of the period hold out much optimism about the power of legal regulation to provide protection or recourse.

\footnotetext{
${ }^{60}$ See Erik F. Gerding, Law, Bubbles and Financial Regulation (Abingdon and New York: Routledge 2014) p.74 ff. These abuses included false accounting, using the names of reputable people as directors without permission; misleading statements in prospectuses, and the creation of sham companies.

${ }^{61}$ Ibid., p.76

${ }^{62}$ This year also saw the establishment of the Bank of England as lender of last resort in crises.
} 
We have already seen that gentility — or at least the outward markers of gentle status - could no long be relied upon as marks of honour or reliability. But could the gradual emergence of professional standards in fields such as law, politics or accounting be relied upon to fill in for the moral vacuum which seemed to have emerged amid a burgeoning market economy which encourage speculative investment and even sharp practice alongside a morally and economically imploding old order? The nineteenth century was, after all, an age of rapid professionalization, and the essence of that process in fields such a law, accounting, journalism, medicine, politics and the church — even the arts, including literature — was a standardisation of mechanisms of accreditation and of accountability. ${ }^{63}$ Law and other professional structures stood in, in other words, for older codes of honour. ${ }^{64}$ But were they capable of doing so adequately?

Since professions were themselves in some real sense the creature of capitalism - a means of reconciling norms of politeness and social standing with the need to earn a living in the move away from an agricultural, neo-feudal economy — there might well be cause for some scepticism about this. And judging by Trollope's fictional output, he and his contemporaries were far from convinced. In each of the professional spheres which his work encompasses, he represents a complex and generally unsatisfactory interplay between old and new resources of regulation: a world in transition, we might say, where unintended outcomes arise from the interaction between different moral economies of trust and credit. Let us start with politics. Many of the Trollope's 'new' politicians, like Phineas Finn (of the eponymous novel (1869) and Phineas Redux (1874)) and Francis Tregear, are gentlemen but without resources, and hence have to balance their commitment to politics as a vocation with a struggle earn their living. This imperative makes it very hard for them to escape from dependence on traditional sources of wealth, notably elite patronage; and this in turn compromises the independence which is central to their implicit definition of professional standards. In the age of reform, the gradual emergence of politics itself as a profession was surely one of the most potent symbols of a changing distribution of power across the classes, accelerating with every Reform Act, and leaving the bourgeois class, which had been in a minority at the outset of the Century, with clear dominance by its end. Yet in politics as in law, the ancient marks of credit and character - the House of Lords, parliamentary rituals, systems of patronage - long outlasted the system which had borne them, and constantly disrupted the claim to reason and modernity central to the project of reform.

In the Barchester novels (1855-1867), the church, too, is depicted as uncomfortably divided between old and new regimes, with the Proudies and Slopes of the new order mounting a challenge to the Hardings and Grantlys of the old

\footnotetext{
${ }^{63}$ See Nicola Lacey 'The Way We Lived Then: The Legal Profession and the Nineteenth Century Novel,' 33 Sydney Law Review (2011) pp.599-621; 'What constitutes criminal law?', in R.A Duff, L. Farmer, S. Marshall, M. Renzo and V. Tadros (eds.) The Constitution of the Criminal Law (Oxford University Press 2013) pp.12-29.

${ }_{64}$ Michie, 'Buying Brains’ op. cit., p.91.
} 
order - a challenge which the old order is scarcely morally or practically equipped to meet. While Trollope is far from endorsing its legitimacy, he is also clear-sighted about the complacency and, sometimes, corruption of the old order - a system in which unscrupulous newcomers like Slope can have a great deal of power, and in which the inequities of the old order leave inadequately remunerated clergy like Josiah Crawley vulnerable to the pressures and pitfalls of the emerging monetary order. Certainly, balanced figures like Mr Arabin are held out as a model - but one that is not sufficiently institutionalised to offer a reliable source of stability. It is probably in the law, however, that the unstable - even toxic - mix of old and new orders produces its most pathological results. ${ }^{65}$ And this is as evident in Orley Farm as it is in The Way $W$ e Live Now. Moreover journalism - another emerging profession which features regularly in Trollope's work - is represented as vulnerable to the lure of instrumental calculation and the hunt for profit, as is caustically implied in the Lady Carbury's carefully crafted letters to three editors, soliciting favourable reviews of her forthcoming book, in the opening chapter of The Way We Live Now. ${ }^{6}$ And much the same is true, as we shall see in the next section, of Trollope's depiction of the legal profession.

\section{The Contrasting Worlds of Orley Farm and Melmotte's London: Money versus Old Property; Pathologies of Legal Regulation}

In Orley Farm, Trollope offers a remarkably sympathetic account of the fate of a female forger - and a remarkably nuanced account of the interplay between old and new normative regimes in shaping her fate. Lady Mason, aggrieved by what she sees as her husband's unjust refusal to leave their home, Orley Farm, to their son Lucius, forges a codicil to the will in which he had left it to Joseph, the son of his previous marriage, who has already inherited the family seat in Yorkshire. Joseph Mason challenges the will, but it is found to be valid. Years later, as Lucius comes of age and takes up his responsibilities as heir to Orley Farm, a local attorney who has an animus against him uncovers further evidence which he takes to Joseph Mason, prompting further legal investigation. This ultimately results in Lady Mason's trial for perjury in the original case. She is acquitted, but has already confessed her guilt to two close friends and, on the eve of her acquittal, to her son; and the estate is surrendered to Joseph Mason notwithstanding the acquittal.

For our purposes, several things are of interest about this magnificent novel. First, though both Orley Farm and The Way We Live Now turn on a grievous instances of proprietary dishonesty, the worlds within which the respective frauds occur could

\footnotetext{
${ }^{65}$ See Nicola Lacey 'The Way We Lived Then: The Legal Profession and the Nineteenth Century Novel' op. cit.; Jan-Melissa Schramm, Testimony and Advocacy in Victorian Law, Literature and Theology (Cambridge University Press, 2000).

${ }^{66}$ Op. cit., Chapter I: in her letter to Mr. Alf, Lady Carbury explicitly alludes to the norm that praise should be 'bought by neither money nor friendship' [5] even as she solicits precisely this bargain. See also Chapter XXX.
} 
not be more different. It makes all the difference to Trollope, it seems, that the object of Lady Mason's fraud is not money but land - indeed family land which she has some cause to think should justly have been willed to her son. ${ }^{67}$ Although brought up to over-value money, she has schooled herself expertly in the gentle norms of proprietary propriety, at least as far as social appearances are concerned. Indeed, Trollope is meticulous in convincing us that Lady Mason has done all in her power to distance herself from base financial motives: she has asked nothing for herself, and is motivated by a sense of maternal responsibility symbolised by her appeals to the biblical model of Rebekah. Second, though much of the novel centres on the preparations for and course of a trial, and many of its protagonists are lawyers or key witnesses in that trial, the law itself plays next to no role in the practical outcome. The law, indeed, has been impotent to expose Lady Mason's fraud. And it has been impotent precisely because of the powerful interplay of old and new symbolic resources. The technical skills of Mr Chaffanbrass are used, as we have seen, to neutralise the reputation of Mr Dockwrath, manipulating the markers of credibility so central to the evaluation of any testimony.

Yet more strikingly, the various professionals involved - and on both sides are keen to see Lady Mason acquitted even though most of them are absolutely convinced of her guilt. In this they are driven both by their sense of her feminine charms but also their evaluation of her relative gentility as compared with the vengeful cupidity of both Joseph Mason and Samuel Dockwrath. In advising her, her barrister and admirer Mr Furnival is moreover meticulous in underlining to her the importance of managing her public reputation and high status networks in the run up to the trial. In fact, this is a lesson which Lady Mason does not need to be taught, since she has internalised it decades ago and put it into practice quite consistently. Indeed, her present danger is caused entirely by her son's decision to step outside this carefully managed strategy on the basis of what is, in effect, a proprietary and legal motivation: he angers Dockwrath by insisting on his right to terminate the rental of two fields. In this story, then, the combination of law and the economy of honour directly and effectively obstructs the delivery of truth. No wonder that a key theme of the novel is its swingeing critique of a legal system in which advocacy can be bought and, in effect, truth is at the command of money.

Many of the 'gentlefolk' - legal and otherwise - of the rather different milieu of The Way We Live Now, similarly support and associate with Melmotte, for a remarkably extended period, despite being perfectly convinced that he is a 'swindler and a thief. In the case of Lady Carbury, 'She cared nothing for Melmotte's villainy.... That he was enriching himself by the daily plunder of the innocent she had taken for granted since she first heard of him'.68 And Georgiana Longstaffe goes to stay with the Melmottes irrespective of the fact that she had long assumed him to be mired in dishonesty. ${ }^{69}$ And Melmotte constructs his artificial financial

${ }^{67}$ On Trollope's attitude to primogeniture, see Saul Levmore, 'Primogeniture, Legal Change, and Trollope', in Nussbaum and Lacroix op. cit., pp.216-229; see also note 55 above.

68 The Way We Live Now p.467

69 Ibid Chapter XXXII [137] 
empire in the heart of the city, with the imprimatur of his parliamentary credentials, and with the help rather than the hindrance of the legal system and its actors.

While, as we have seen, Slow and Bideawhile are just as dozy and ineffective in The Way We Live Now as in Orley Farm, and eager younger lawyers like Squercum anything but appealing, it is interesting that Trollope in the later novel shows a slightly greater respect for his professional skill — just as Mr Chaffanbrass gets a better press from Trollope when he steps in effectively to defend Phineas Finn in Pbineas Redux. Yet the fact remains that all the rules and regulations put in place to discipline the conduct of commercial, financial and banking activity in the second half of the nineteenth century are in effect portrayed as quite impotent in the face of the determined fraud of Melmotte, toxically combined as it is with the continuing power of the old order of the external marks of honour. Indeed, in an apparently pessimistic view of the power of legalism, Trollope depicts Melmotte as studying the law to see just how close he can sail to the wind in his commercial dealings. ${ }^{70} \mathrm{It}$ is this very lack of faith in regulation or reform which makes The Way We Live Now stand out among Trollope's generally rather sanguine work, marking its quality as a social dystopia rather than merely a tale of individual bad character.

\section{MONEY AND GENDER}

It is interesting, finally, to consider the lessons which these two fine novels have to teach about late Victorian attitudes to gender, money and other forms of property. Especially for middle-class women, excluded by both legal norms and norms of respectability from most careers, the problem of money was a pressing, often a desperate one. Hence novels throughout the nineteenth-century are peppered with intelligent single women struggling to support themselves while preserving their social respectability - Charlotte and Anne Brontë's reluctant governesses and schoolteachers, Jane Eyre, Lucy Snowe, Agnes Grey ${ }^{71}$ — are one particularly eloquent example, just as are Trollope's ageing spinsters like the unlovely Georgiana Longstaffe, whirling in an ever more desperate way around the balls and house parties where they may "catch" a husband.72 Notwithstanding Trollope's

\footnotetext{
70 The Way We Live Now op. cit., pp.470-471

${ }^{71}$ Charlotte Brontë, Jane Eyre (1847), and Villette (1853); Anne Brontë, Agnes Grey (1847).

72 This was a situation that Trollope had watched his own niece, his brother's daughter Bice, endure over several years: see Victoria Glendinning, Anthony Trollope, pp. 357-358. Cf. the situations of Augusta Gresham and Lady Alexandrina de Courcy in Dr. Thorne (1858) and The Small House at Allington (1864), as well as the increasingly desperate Georgiana Longstaffe in The Way We Live Now (1875). On marriage and husband hunting in Trollope, see Margaret Markwick, Trollope and Women (Hambledon Press, 1997) pp.95126. Other critical works dealing with Trollope's attitude to women and to gender relations include Jane Nardin, He Knew She Was Right: The Independent Woman in the Novels of Anthony Trollope (Southern Illinois University Press, 1989); Margaret Markwick, New Men in Trollope's Novels (Ashgate, 2007); Margaret Markwick, Deborah Denenholz Morse, and Regenia Gagnier, eds., The Politics of Gender in Anthony Trollope's Novels (Ashgate, 2009). On the declining acceptability of women's asserting their rights as read through patterns of litigation and literary representation of the breach of promise action, see Saskia Lettmaier, Broken Engagements: The Action for Breach of Promise of Marriage and the Feminine Ideal, 1800-1940 (Oxford University Press, 2010).
} 
affirmation of the appropriateness of the desire to acquire property, the line which his female characters have to tread in order to pursue it in an appropriate way is a narrow one. Too great a monetary consciousness is, in short, unfeminine: and in some ways one feels that Trollope more kindly predisposed to dishonest Lady Mason, who obeys the norms of feminine and maternal propriety, and keeps her feminine credentials free of market corruption, than to Marie Melmotte, who knows the value of money and seeks to control it. Indeed he rather sneers at her, in terms that explicitly evoke proto-feminist language: 'She also had a conception of women's rights - especially in regard to money'. ${ }^{73}$ But, ultimately, one suspects that had Felix and Marie managed to execute their elopement plan and appropriate the settled money, they might well have been to some extent socially rehabilitated. After all, another of Trollope's female property offenders, Lady Eustace, who is likely guilty of theft, serves to illustrate his view of the redeeming social power of money. ${ }^{74}$ She reappears on the margins of respectable society in The Prime Minister (1876) rehabilitated by her money, beauty, and wit - at least among those ambitious to entertain titled guests but lacking the social influence to attract more respectable examples. Accordingly, 'there were... others who declared that no decent man or woman ought to meet her'. ${ }^{75}$ In each of these examples, the normative force of overlapping systems - of gender, of law, or older codes of honour and propriety - intersect with, and affect, the primal power of money.

\section{CONCLUSION: 'MR MELMOTTE'S PROMISE'76}

In short, in these two fine novels, Trollope gives us a fascinating picture of a world in transition: a world in which the old markers of credit and status are still in place, mixing in sometimes quite toxic ways with the new and dominant technologies of money, economic instrumentalism and commercial ambition; and a world in which governmental attempts at centralisation, standardisation and regulation have had, at best, uneven effects. Unlike Dickens, then, Trollope does not here present us with a rallying cry to social reform. Rather, and in a notably balanced way, he invites us to reflect on the continuing ambivalence of money in a world which, though nothing like as fast-moving and market-driven as ours, is fundamentally recognisable nearly 150 years on..$^{77}$ Above all, he invites us to ponder the way in which human pecuniary

\footnotetext{
73 The Way We Live Now op. cit., p.750. Indeed, Trollope describes Marie's plan to elope with Felix and live on the money which her father has settled on her — one assumes, for dubious purposes — as an intention to 'rob' (Chapter XXIX [127]).

${ }^{74}$ The Eustace Diamonds (1873): a book in which the law, which struggles to determine the legal status of a priceless set of diamonds, is represented as hopelessly indeterminate and archaic.

75 See The Prime Minister., p.79; see further, Nicola Lacey, 'Could He Forgive Her? Gender, Agency and Women's Criminality in the Novels of Anthony Trollope', in Martha C. Nussbaum and Alison Lacroix (eds.), Subversion and Sympathy: Gender, Law and the British Novel (Oxford University Press 2013) pp.176-204

76 As Trollope entitled Chapter 30 of The Way We Live Now.

77 It is interesting to speculate on how Trollope would have regarded our chances of effectively regulating the newly emerging, decentralised forms of money such as 'bitcoin,' which deploys non-state solutions to
} 
motivations play out amid the contingencies of character under social and economic conditions which hold out enormous gains for financial risk-takers - and match these with mixed messages about how economic motivation should be tempered by moral considerations.

the longstanding structural problems of trust, double spending and enforcement afflicting paper and virtual pecuniary forms. 